\title{
実験的高コレステロール血に関する研究 (I) \\ Experimental Studies on Hypercholesteremia (I)
}

鯨油高度不飽和脂肪酸の実験的白ネズミ高コレステロール血に及ぼす影響

Effects of polyunsaturated fatty acid in whale oil on experimental

hypercholesteremia of rats

(昭和 38 年 3 月 20 日受理)

$$
\begin{gathered}
\text { 馬 } \underset{\text { (Yasumasa }}{\text { 安 }} \text { Majima) }
\end{gathered}
$$

\footnotetext{
Polyunsaturated fatty acid in whale oil was effective in suppressing hypercholesteremia in rats caused by palm oil. It was effective with a half amount of linolic acid and was not interfered even with less than a half of palmitic acid.
}

動脈硬化症と血清コレステロールの上䄯，すなわち高 コレステロール血との間には密接な関係があり, 高コレ ステロール血を起こす原因およびこれを低下させる原因 の1つとして最近脂質摄取が問題視されてきた。Deuelな

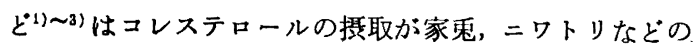
血清コレステロール值を上䄯させるといい，またラード などの動物脂肪摂取では上䄯させるが植物脂肪搨取では かえって低下させること，そして殊にコーン油はその作 用の強いことなどがわかってきだ)〜13)。そしてさらにこ の低下作用がそれら脂肪中の不飽和脂肪酸とくに高度不 㿣和脂肪酸によるらしいことが明らかになってきた。 そこでこの脂肪酸の效果が必須脂肪酸として，すなわ ち $\mathrm{CH}=\mathrm{CH} \cdot \mathrm{CH}_{2} \cdot \mathrm{CH}=\mathrm{CH}$ の存在するためなのか, 或 いは二重結合の存在するためなのか大変興味ある問題と なってきたので, 鯨油の高度不飽和脂肪酸（二重結合 4 つ以上で主として縕酸) を用い、リノール酸と比較しな がら白ネズミを用いてこの低下作用，およびこのときの 的和脂肪添加の影響などについて検討しょうと考えこの 実験を始めた。そして鯨油高度不飽和脂肪酸はリノール
酸の半量で十分效果のあること，また飽和脂肪酸（パル ミチン酸) の添加も少量であればこの低下作用に影響し ないことなど少しす゚つわかってきた。殆んど同時にWo_ $\mathrm{rne}^{20) \sim 22)}$ なども種々の高度不飽和脂肪酸を用いて同椂 実験し，二重結合の增加する程低下作用の強いことを報 告してきた。このようにこれら問題も少しずつ解明され つつあるが未だ不明の点も多い上うである。現在までの 結果をここに報告する。

\section{1. 実験材料および方法}

体重 $150 \mathrm{~g}$.前後の白ネズミ(主としてる)を用いて保温 箱 $\left(20 \sim 35^{\circ} \mathrm{C}\right)$ 中で飼瓷した。飼料は次の上うな基本飼料 を用いた。これに脂質としては実験条件に応じてオンフ 油, 旧麻仁油, 楖子油, コレステロール,ラノリン, パルミ チン酸、リノール酸扣上び鯨油高度不飽和脂肪酸をそれ ぞれ用いた。鯨油高度不飽和脂肪酸 (二重結合 4 つ以上) は鯨油より図 1 のようにしてェチルェステルとして亦収 した。他は市販品を用いた。

\begin{tabular}{|c|c|c|c|}
\hline & 基 & 料 & \\
\hline 脱脂カゼイン & $12 \mathrm{~g}$ & ビタミン $\mathrm{B}_{12}$ & $0.002 \mathrm{mg}$ \\
\hline 蔗＼cjkstart糖 & $37 \mathrm{~g}$ & ニコチン酸 & $20 \prime \prime$ \\
\hline 湃 粉 & $37 \mathrm{~g}$ & 塭酸チアミン & $2 " \prime$ \\
\hline オレフ 油 & $10 \mathrm{~g}$ & リボフラビン & $3 \prime \prime$ \\
\hline マッカラム塩 & $4 \mathrm{~g}$ & 塩酸ピリドキシン & $3 \prime \prime$ \\
\hline ビタミンA（パルミテート） & $3,000 \mathrm{I} . \mathrm{U}$ & パントテン酸カルシウム & $11 \prime$ \\
\hline ビタミンD（パルミテート） & 400I. U. & ビタミンK & $0.4 \prime \prime$ \\
\hline 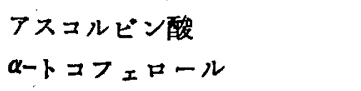 & $\begin{array}{r}75 \mathrm{mg} \\
2 \mathrm{mg}\end{array}$ & \multicolumn{2}{|c|}{ 脱脂カゼインは温エタノールとエーテルで洗淮) } \\
\hline
\end{tabular}

白ネズミは一定期間飼養後䅡部を切って殺し，血清中 
図 1 鯨油高度不館和脂肪酸製収法

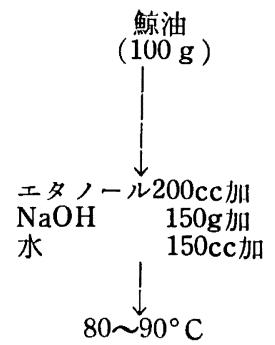

10 分間睮化

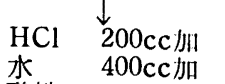

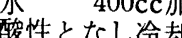

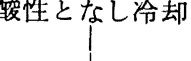

エーテル抽出

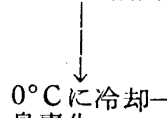

臭素化
$\frac{\mathrm{N}}{5} \mathrm{HCl}$ エタノール $100 \mathrm{cc}$ 加一 $80^{\circ} \mathrm{C} 2$ 時間 脱臭素

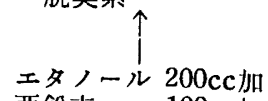

亜鉛末 $100 \mathrm{~g}$ 加

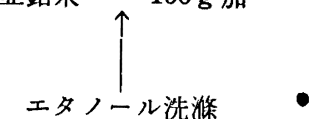

沪過

クロロホルム洗湺

沪過

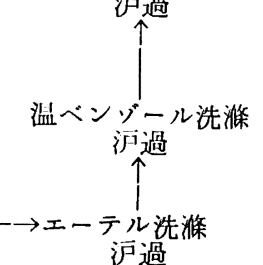

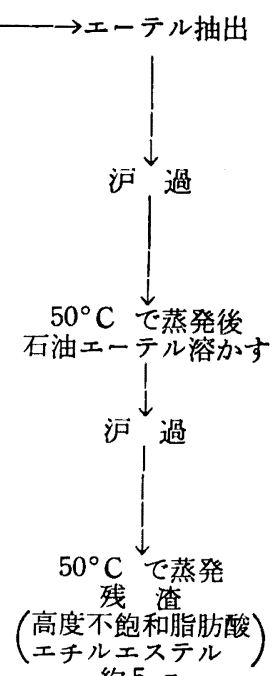

約 $5 \mathrm{~g}$
のエステルおよび遊離コレステロールを Schönheimer 法 $^{23)}$, 総コレステロールを Zak 法24)で測定した。

\section{2. 実験成績および考案}

種々の脂質を用いて実験的に白ネズミに高コレステロ ール血を起こさせる条件を検討した。

基本飼料に脂質としてオレフ油10\%，オレフ油10\%+

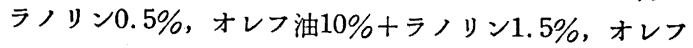
油 $10 \%+$ ニステロール $0.5 \%$,オレフ油10\%+コレス テロール $1.5 \%$ ，梛子油 $10 \%$, 同 15\%, 楖子油 $10 \%+$ ○ ノリン $1.5 \%$ ，楖子油10\%+コレステロール1.5\%，覀麻 仁油10\%，鯨油（マッコウでないるの）10\%をそれぞれ 用いて白ネズミ（約 $150 \mathrm{~g}$ )を長期間飼養し血清中のエス テルおよび遊離コレステロールを測定したところ表 1 の 上らな結果が得られた。すなわち白ネズミはす各々 3 〜 4 匹を用い 8 週より18週飼盖したときの体重の変化は コレステロール添加時の成長が $\delta$ 共に悪く, 次いで㑡

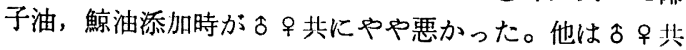
に比較的よく增加した。血清中のコレステロール値は才 レフ油にコレステロール $0.5 \% ， 1.5 \%$ 添加時，打よび楖 子油 $10 \% ， 15 \%$ 添加時にはす \&共に 8 週以上で著しく約 $300 \mathrm{mg} \%$ にまで增加した。この增加は梛子油とコレステ ロール同時添加ではさらに約 $400 \mathrm{mg} \%$ と著明であった。 しかしラノリン,オレフ油, 重麻仁油, 鯨油では飼盖前 とあまり变らず增加しなかった。このよ5にコレステロ ールなどの 8〜10週の添加で300mg\%〜400mg\%に增加 したことはWissler ${ }^{25) 1}$ などの白ネズミを用いた実験と 比べて少し早いようであるが，種々条件の差異によるた めと思われる。また血清コレステロールはコレステロー
ル添加時に遊離型が楖子油添加時にエステル型が增加し た。これは大変興味があるので次の機会にさらに検討し たいと考えている。食品中のコレステロールの含有量は あまり多くないので以上の実験結果から実際問題と合せ 考光, 楖子油 $10 \%$ 添加で。白ネズミ 8 週以上飼養が高コ レステロール血を起こす条件として適当であると思われ るのでこれを用いて実験を進めることにした。

白ネズミ（る約 $150 \mathrm{~g}$ )を 5 群に分から 1 群には脂筫と して基本食慨にリノール酸 $0.7 \%$ 添加， 2 群は鯨油高 度不飽和脂肪酸エチルエステル $0.7 \%$ を添加，3群には 梛子油 $5 \%$ と同時にリノール酸 $0.7 \%$ を添加，4群には 梆子油 $5 \%$ と同時に鯨油高度不飽和脂肪酸エチルエステ ル0.7\%を添加, 5 群は脂質を除いて無脂肪とし 8 週間飼 養後血清中総コレステロールを測定した。その結果，表 2 のよ5に体重增加は各群共大なる差はなかった。血清 総コレステロールは必須脂肪酸の白ネズミ必要量である $0.7 \%$ リノール酸添加の 1 群扰よび 同量の鯨油高度不 飽和脂肪酸添加の 2 群では無脂肪5 群よりやや低く共に70 $\mathrm{mg} \%$ 前後の值を示し添加前と殆んど変わらず增加しな かった。白ネズミの血清総コレステロール正常値は70土 $25 \mathrm{mg} \%{ }^{28 \sim 28)}$ である故正常値を維持したことになる。し かしこれに梛子油 $5 \%$ が加わった $3 ， 4$ 群では共に約 140 $\mathrm{mg} \%$ に增加した。このよ 5 に鯨油高度不飽和脂肪酸は リンール酸の必要量の $0.7 \%$ で血清コレステロールを增

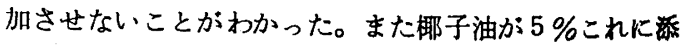
加されるとリノール酸同様增加してきた。これは那子油 中の餙和脂肪酸のためと思われ, 両脂肪酸共これによっ て影響されることがわかった。

次に同様ふ白ネズミを楖子油10\%添加で 8 週間飼盖し 
第 16 巻 第 4 号

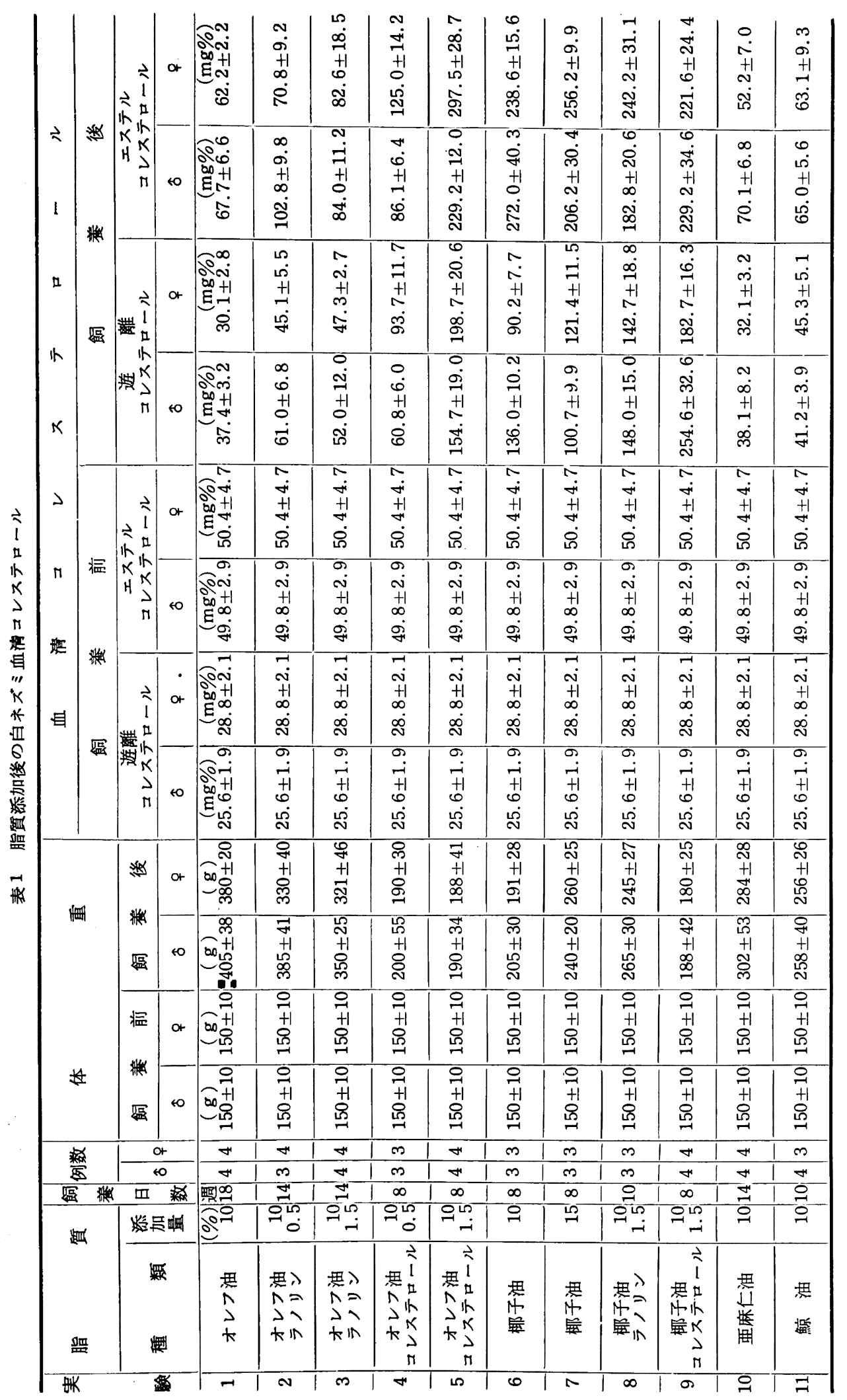


表 2 脂肪酸添加後の血清コレステロール

\begin{tabular}{|c|c|c|c|c|c|c|c|c|c|}
\hline \multirow{2}{*}{ 実験 } & 脂 & \multicolumn{2}{|c|}{ 酸 } & \multirow{2}{*}{$\begin{array}{l}\text { 飼盖数 } \\
\text { 数 }\end{array}$} & \multirow{2}{*}{ 例数 } & \multicolumn{2}{|r|}{ 重 } & \multicolumn{2}{|c|}{ 血清総コレステロール } \\
\hline & 種 & 類 & 添加量 & & & 飼養 前 & 飼養 後 & 飼 養 前 & 飼 養 後 \\
\hline 1 & & ᄂ酸 & $\begin{array}{l}(\%) \\
0.7\end{array}$ & (㛠) & 4 & $\begin{array}{c}(\mathrm{g}) \\
150 \pm 12\end{array}$ & $\begin{array}{c}(\mathbf{g}) \\
228 \pm 38\end{array}$ & $\begin{array}{r}(\mathrm{mg} \%) \\
75.4 \pm 6.0\end{array}$ & $\begin{array}{r}(\mathrm{mg} \%) \\
70.6 \pm 9.2\end{array}$ \\
\hline 2 & $\begin{array}{r}\text { 鯨 } \\
\text { 不飽 } \\
\text { 工手 }\end{array}$ & $\begin{array}{l}\text { 度 } \\
\text { 肪酸 } \\
\text { ステル }\end{array}$ & 0.7 & 8 & 4 & $150 \pm 12$ & $209 \pm 22$ & $75.4 \pm 6.0$ & $73.2 \pm 5.5$ \\
\hline 3 & & & $\begin{array}{c}0.7 \\
5\end{array}$ & 8 & 4 & $150 \pm 12$ & $195 \pm 35$ & $75.4 \pm 6.0$ & $142.1 \pm 9.9$ \\
\hline 4 & 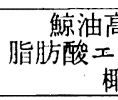 & $\begin{array}{l}\text { 不飽和 } \\
\text { エステル } \\
\text { 由 }\end{array}$ & $\begin{array}{c}0.7 \\
5 \\
\end{array}$ & 8 & 4 & $150 \pm 12$ & $236 \pm 24$ & $75.4 \pm 6.0$ & $148.1 \pm 33.0$ \\
\hline 5 & & & & 8 & 4 & $150 \pm 12$ & $212 \pm 42$ & $75.4 \pm 6.0$ & $92.7 \pm 30.1$ \\
\hline
\end{tabular}

図 2 脂肪酸投与後の体重の変化

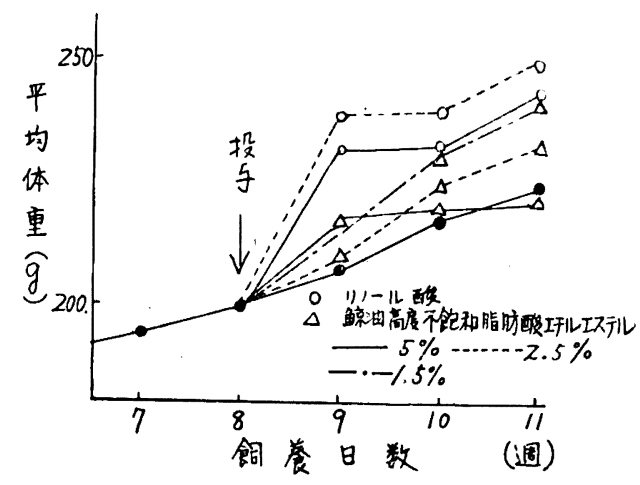

高コレステロール血を起こさせたものを 6 群に分かち， 1 群には㑡子油10\%の他にリノール酸 $2.5 \%$ を, 2群には 同様りノール酸 $5 \%$ を，3 群には同㥞鯨油高度不飽和脂 助酸エチルェステル $1.5 \%$ を, 4 群には同㥞同脂肪酸 $2.5 \%$ を， 5 群には同椂脂肪酸 $5 \%$ を添川し，6 群はそのまま 対照とした。

投与 3 週後の結果は図 2 の上5に, その体重の变化は リノール酸 $2.5 \% ， 5 \%$ 投与群は対照の無投与群に比べ て著明に增加した。倞油高度不館和脂肪酸エチルエステ ル1.5\%，2.5\%投与群もリノール酸投与群同梯增玑した が，5\%投与群では対照と同程度で增加しなかった。楖 子油および基本飼料中には必須脂肪酸は殆んど含有して いないので挪子油10\%添加で 8 週間飼虽したときは，必 須脂肪酸火乏状柋にあるのでリノール酸投与で体重が增 加ナるのは当然であるが，解油高度不飽和脂肪酸 $1.5 \%$, $2.5 \%$ 投与でもリノール酸よりその程度はやや少ないが 增加を示すのは興味があ。しかし $5 \%$ ではかえって娍 少するのはそれ自身の毒性のため（過酸化物が生成され たか）か子知れない。

血清総コレステロールは表 3 のよ5にリノール酸 $5 \%$
衣3高コレステロール血を起こした白ネズミに 脂肪酸を投与したときの血清コレステロー ルの变化

\begin{tabular}{|c|c|c|c|c|c|c|c|}
\hline \multirow{2}{*}{ 赛 } & \multirow{2}{*}{$\begin{array}{l}\text { 脂 } \\
\text { 種 }\end{array}$} & \multirow{2}{*}{$\frac{\text { 肪 }}{\text { 類 }}$} & \multirow{2}{*}{$\frac{\mid \text { 酸 }^{\prime}}{\mid \text { 投与 }}$} & \multirow{2}{*}{ |投与 } & \multirow{2}{*}{ 例 } & \multicolumn{2}{|c|}{ 血清総コレステロール } \\
\hline & & & & & & 投与前 & 投与後 \\
\hline 1 & リノ & ール酸 & $\begin{array}{l}(\%) \\
2.5\end{array}$ & $\left(\frac{\text { (週) }}{3}\right.$ & 4 & $\begin{array}{c}(\mathrm{mg} \%) \\
195.0 \pm 26.0\end{array}$ & $\begin{array}{c}(\mathrm{mg} \%) \\
196.0 \pm 20.7\end{array}$ \\
\hline 2 & リノ & ール酸 & 5 & 3 & 4 & $195.0 \pm 26.0$ & $132.0 \pm 10.8$ \\
\hline 3 & 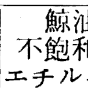 & $\begin{array}{l}\text { 高度 } \\
\text { 脂肪酸 } \\
\text { こステルル }\end{array}$ & 1.5 & 3 & 4 & $195.0 \pm 26.0$ & $189.4 \pm 30.2$ \\
\hline 4 & 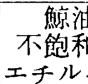 & $\begin{array}{l}\text { 高度 } \\
\text { 脂䏚酸 } \\
-ス テ ル 2\end{array}$ & 2.5 & 3 & 4 & $195.0 \pm 26.0$ & $136.3 \pm 29.6$ \\
\hline 5 & $\begin{array}{l}\text { 䭘测 } \\
\text { 不飽和 } \\
\text { エチル }\end{array}$ & 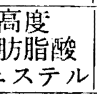 & 5 & 3 & 4 & $195.0 \pm 26.0$ & $130.4 \pm 22.2$ \\
\hline & & ま & & & 3 & $195.0 \pm 26$. & $205.0 \pm 19.5$ \\
\hline
\end{tabular}

投与群では，投与前の約 $195 \mathrm{mg} \%$ に比べて約 $132 \mathrm{mg} \%$ と相当量減少した。しかし $2.5 \%$ 投与群では効果なく約 $196 \mathrm{mg} \%$ と变わらなかった。鯨油高度不飽和脂肪酸エチ ルエステルでは $1.5 \%$ 投与群では䄪 $189 \mathrm{mg} \%$ と変わらな かったが，2.5\%，5\%投与群では共に約 $136 \mathrm{mg} \% ， 130$ $\mathrm{mg} \%$ とリノール酸 $5 \%$ 群と同程度堿少した。このよ 5 K リノール酸が楖子油による高コレステロールを低下させ ることは礁かであるが大量を用いないと效果のないこと 鯨油高度不飽和脂肪酸エチルエステルはその半量で効果 があるが大量だと体重娍少をきたし，少こし毒性がある らしいことがわかった。

そこで体重減少を少こしでも防ぐため鯨油高度不飽和 脂肪酸エチルェステル慗収時の最後のエーテル溶液中 に $\alpha$ ートコフェロールを脂肪酸量に対し $2 \%$ の割合で混 入し，これを用いて上述同栚低下作用をしらべ，合せて 
そのときのパルミチン酸同時投与の影響を実験した。す なわち楖子油 $10 \%$ 添加 9 週後の白ネズミ（ઠ）を10群に分 から脂肪として 1 群にはリノール酸 $5 \%$ 投与， 2 群には リノール酸 $5 \%$ にハルミチン酸 $1.5 \%$ 同時投上, 3 群には リノール酸 $5 \%$ \%パルミチン酸 $2.5 \%$ 同時投与, 4 群に はリノール酸 $5 \%$ とパルミチン酸 $5 \%$ 同時投与, 5 群に

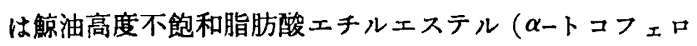
一ル含有） $2.5 \%$ 投与， 6 群には同酸 $2.5 \%$ とハルミチン 酸 $1 \%$ 同時投与， 7 群には同酸 $2.5 \%$ とパミチン酸 2.5 \%同時投与，8群には同酸 $2.5 \%$ と゚ルミチン酸 $5 \%$ 同 時投与, 9 群は投与世ず無脂肪食慨となし，10群は楖子油 10\%でそのまま続けた。投与 3 週後の体重の変化は図 3 のよ5に各群共無脂肪食慨群, 楖子油群を除き比較的よ く增加した。これによって抗酸化剤の添加によって白ネ ズミの鯨油高度不飽和脂肪酸エチルエステルによる体重 堿少が相当量軽減されるらしいことがわかった。

図 3 脂肪酸投与後の体重の变化

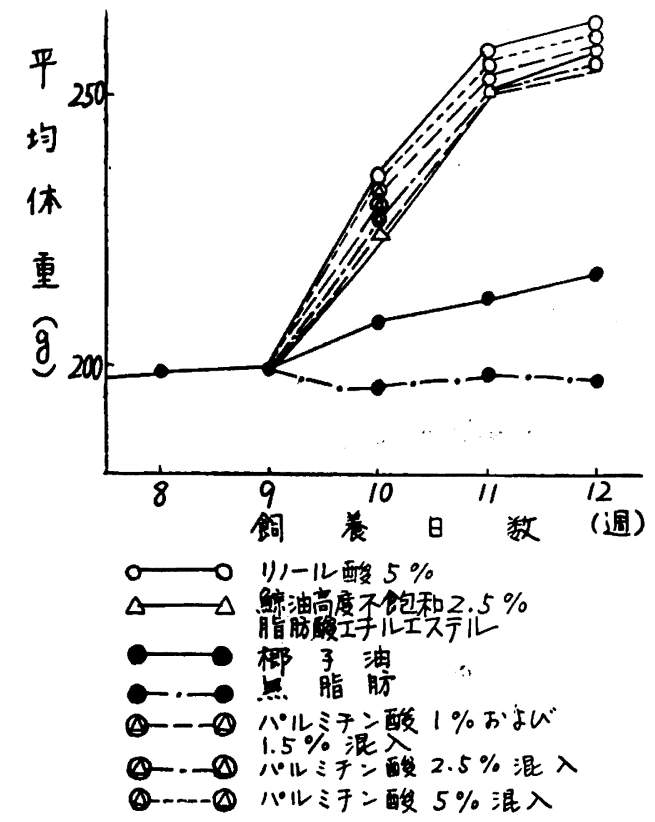

血清総コレステロールの变化は表 4 のように梛子油を 除きリノール酸 $5 \%$ 投与の 1 群，扣よび同栐鯨油高度不 飽和脂肪酸エチルエステル $2.5 \%$ 投与の 5 群では投与 3 週後に血清コレステロールは共に約 $98 \mathrm{mg} \%, 99 \mathrm{mg} \%$ と 楖子油の除いてない場合（表 3 ）よりさらに著しく低い 值を示した。楖子油を除いた無脂肪食䬦の 9 群でも，約 $104 \mathrm{mg} \%$ と著明に低下したが，1，5群よりその低下作用は 少し弱かった。リノール酸および鯨油高度不飽和脂肪酸 エチルエステルにパルミチン酸を加えて投与した場合は $1.5 \%(1 \%), 2.5 \%, 5 \%$ 加えた $2,3,4$ 群扰よび 6 ， •7, 8 群共に約 $102 \mathrm{mg} \%$ より䄪 $150 \mathrm{mg} \%$ その最が增加
表 4 高コレステロール血を起こさせた白ネズミ に脂肪酸を投与したときの血清コレステロ ールの変化

\begin{tabular}{|c|c|c|c|c|c|c|}
\hline \multirow{2}{*}{ 泰 } & \multicolumn{2}{|l|}{ 肪酸 } & \multirow{2}{*}{ 投与 } & \multicolumn{3}{|c|}{ 血清総コレステロール } \\
\hline & 棰 & $\left|\begin{array}{l}\text { 投与 } \\
\text { 量 }\end{array}\right|$ & & 数 & 投与前 & 投与後 \\
\hline 1 & リノール酸 & $\begin{array}{r}(\%) \\
5\end{array}$ & $\frac{(\text { 週 })}{3}$ & 4 & \begin{tabular}{c|}
$(\mathrm{mg} \%)$ \\
$198.0 \pm 20.0$
\end{tabular} & $\begin{array}{c}(\mathrm{mg} \%) \\
98.2 \pm 10.2\end{array}$ \\
\hline 2 & $\begin{array}{l}\text { リノール酸 } \\
\text { パルミチン酸 }\end{array}$ & $\begin{array}{r}5 \\
1.5\end{array}$ & 3 & 4 & $198.0 \pm 20.0$ & $102.3 \pm 9.7$ \\
\hline 3 & $\begin{array}{l}\text { リノール酸 } \\
\text { パルミチン酸 }\end{array}$ & $\begin{array}{r}5 \\
2.5\end{array}$ & 3 & 4 & $198.0 \pm 20.0$ & $107.5 \pm 9.8$ \\
\hline 4 & $\begin{array}{l}\text { リノール酸 } \\
\text { パルミチン酸 }\end{array}$ & $\begin{array}{l}5 \\
5\end{array}$ & 3 & 4 & $198.0 \pm 20.0$ & 0147.2 £20.2 \\
\hline 5 & \begin{tabular}{|c|} 
鯨油高度 \\
不飽和脂肪酸 \\
エチルエステル
\end{tabular} & 2.5 & 3 & 4 & $198.0 \pm 20.0$ & 9) $99.6 \pm 7.7$ \\
\hline 6 & $\mid \begin{array}{l}\text { 鯨油高度不館和 } \\
\text { 脂肪酸エチルエ } \\
\text { ステル } \\
\text { パルミチン酸 }\end{array}$ & \begin{tabular}{|r|}
2.5 \\
1
\end{tabular} & 3 & 4 & $198.0 \pm 20.0$ & $0108.3 \pm 11.4$ \\
\hline 7 & $\begin{array}{l}\text { 鯨油高度不飽和 } \\
\text { 脂肪貯エチル } \\
\text { ステル } \\
\text { パルミチン酸 }\end{array}$ & $\left|\begin{array}{l}2.5 \\
2.5\end{array}\right|$ & 3 & 4 & $198.0 \pm$ & $130.2 \pm 20.7$ \\
\hline 8 & 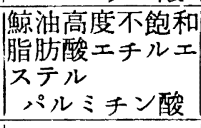 & $\begin{array}{r}2.5 \\
5\end{array} \mid$ & 3 & 4 & $198.0 \pm 20.0$ & $150.6 \pm 7.8$ \\
\hline 9 & 無脂肪 & 0 & 3 & 4 & $198.0 \pm 20.0$ & $0104.6 \pm 2.2$ \\
\hline 10 & 楖子油 & 10 & 3 & 3 & 198.0 上20.0 & $0199.7 \pm 13.6$ \\
\hline
\end{tabular}

するにつれて高い值を示し，コレステロール低下作用は 減弱された。しかしリノール酸 $5 \%$ にパルミチン酸 1.5 $\% ， 2.5 \%$ 加えた $2 ， 3$ 群および鯨油高度不飽和脂肪酸工 チルエステル $2.5 \%$ ル゚ルミチン酸 $1 \%$ 加えた 6 群では 約 $102 \mathrm{mg} \%, 107 \mathrm{mg} \%, 108 \mathrm{mg} \%$ 殆んど增加なくコレ ステロール低下作用があまり減弱されなかった。それ以 上加えた場合に著しく減弱された。このよ5に梆子油を 除いてこの代りにリノール酸の $5 \%$ およびその半量の鯨 油高度不飽和脂肪酸エチルエステルの $2.5 \%$ 投与では共 に楖子油を含んだ同じ場合より 30〜 40\%コレステロール 低下作用が強いこと，そしてこれは磼かにこれら脂肪酸 を投与しない無脂肪の場合よりも作用の強いことがわか $\eta$, 鯨油高度不飽和脂肪酸エチルエステルに， $\alpha$-トコ フェロールを加えるとリノール酸と同様にその成長が殆 んど障害されないことがわかり，またりノール酸の半量 以下扎よび解油高度不飽和脂肪酸の半量以下ならばパル ミチン酸を加えても公んどコレステロール低下作用は減 弱されないことがわかっお。鯨油高度不飽和脂肪酸は主 として鮉酸よりなっているのでコレステロール低下作用 がこの脂肪酸によることは明らかでしかもリノール酸の 
半分で有効である。しかし Worne ${ }^{20)}$ は解酸はリノール 酸の $1 / 4$ 量で有效なことを最近報告してきた。いずれに しても鰛酸の有効なことは確実となってきたが，これの みでは未だ不飽和脂肪酸の有効なのは，その二重結合に あるか否か決定するのは早いようである。しかし 1 つの 暗示は得られる。

また捸取不飽和脂肪酸の血清コレステロール低下作用 に対する飽和脂肪酸の影響について子最近 Hegsted ら 30) 32)の報告があり，ことに Keys ${ }^{32)}$ が搨取脂肪の量と 質と血清コレステロール値との関係について次のような 興味ある公式を提案した。

$\Delta$ Cholesterol $=2.73(\Delta \mathrm{S})+0.01(\Delta \mathrm{M})-1.31(\Delta \mathrm{P})$

$\mathrm{S}=$ Sat urated

$\mathrm{M}=$ Monounsat urated

$\mathrm{P}=$ Polyunsat urated (Linoleic acid)

これによると飽和脂肪酸搨取の影響が強いことを示して いるが，われわれの上述の結果からは二重結合の 2 つ以 上のリノール酸と鯨油高度不飽和脂肪酸共にその $1 / 2$ 量を 境に飽和脂肪酸の影響が現われてくるようである。飽和 脂肪酸の絶対量が関係してくるのか, 或いは楖子油以外 の脂質の違い，すなわち楖子油中の飽和脂肪酸は主とし て低, 中級脂肪酸などで高級飽和脂肪酸による高コレス テロール血, 或いはコレステロール血に対するこれら脂 肪酸の態度の違いなど今後の研究課題として興味がある すのが多い。次にこのコレステロール低下作用を有する
リノール酸 $5 \%$ と鯨油高度不飽和脂肪酸エチルエステル $2.5 \%(\alpha-ト コ フ ェ ロ ー ル$ 含有 $)$ を用い，これにパルミ チン酸を種々の量に加えて白ネズミ（す）を餇養した。白 ネズミ（〕約150 g )を 9 群に分から 1 群にはリノール酸 $5 \%$ \%群にはリノール酸 $5 \%$ とパルミチン酸 $1.5 \%$, 3 群にはリノール酸 $5 \%$ とパルミ゙ンン酸 $2.5 \%$, 4 群に はリノール酸 $5 \%$ とパルミチン酸 $5 \%$ を，5群には觡油 高度不飽和脂肪酸 ( $\alpha$ ートコフェロール含有) $2.5 \%$ を 6 群には同脂肪酸 $2.5 \%$ とパルミチン酸 $1 \%$ を, 7 群には同 脂肪酸 $2.5 \%$ とハルミチン酸 $2.5 \%$ を 8 群には同脂肪酸 $2.5 \%$ パルミチン酸 $5 \%$ を 9 群にはパルミチン酸 $10 \%$ を添加 8 週間飼養後血清総コレステロールを測定した。 その結果は表 5 のよ5であった。体重はリノール酸,觡油 高度不飽和脂肪酸エチルェステル（ $\alpha$ ートコフェロール含 有）共にパルミチン酸を加えたときでも比較的よく增加 したがその量が增加すると体重増加がやや減弱された。 パルミ゙ンン酸10\%添加のときはあまり体重は増加しなか った。血清総コレステロールはリノール酸 $5 \%$, リノー ル酸 $5 \%$ とパルミチン酸 $1.5 \%$,リノール酸 $5 \%$ とパルミ チン酸 $2.5 \%$, 鯨油高度不飽和脂肪酸エチルェステル $(\alpha-$ トコフェロール含有） $2.5 \%$ ，同脂肪酸 $2.5 \%$ とパルミ チン酸 $1 \%$ 1，2，3，5，6 群は飼養前の約 $74 \mathrm{mg} \%$ と あまり変らなかった。リノール酸 $5 \%$ とパルミチン酸 5 $\%$, 䭘油高度不飽和脂肪酸エチルェステル $2.5 \%$ と゚ルミ チン酸 $2.5 \%$, 同脂肪酸 $2.5 \%$ とパルミチン酸 $5 \%$ の, 7 ,

表 5 脂肪酸添加後の血清コレステロール

\begin{tabular}{|c|c|c|c|c|c|c|c|c|}
\hline \multirow{2}{*}{ 実験 } & 脂 & 酸 & \multirow{2}{*}{ 飼㕠日数 } & \multirow{2}{*}{ 例 数 } & \multirow{2}{*}{$\frac{\text { 体 }}{\text { 飼 養 前 }}$} & \multirow{2}{*}{$\frac{\text { 重 }(\hat{o})}{\text { 飼 養 後 }}$} & \multicolumn{2}{|c|}{ 血清総コレステロール } \\
\hline & 種 & 添加量 & & & & & 飼 美 前 & 飼養 後 \\
\hline 1 & リノール酸 & $\begin{array}{c}(\%) \\
5\end{array}$ & （週） & 4 & $\begin{array}{c}(g) \\
150 \pm 11\end{array}$ & $\begin{array}{c}(\mathbf{g ~}) \\
206 \pm 12\end{array}$ & $\begin{array}{c}(\mathrm{mg} \%) \\
74.0 \pm 11.5\end{array}$ & $\begin{array}{c}(\mathrm{mg} \%) \\
70.1 \pm 2.4\end{array}$ \\
\hline 2 & $\begin{array}{l}\text { リノール酸 } \\
\text { パルミチン酸 }\end{array}$ & $\begin{array}{r}5 \\
1.5\end{array}$ & 8 & 4 & $150 \pm 11$ & $213 \pm 24$ & $74.0 \pm 11.5$ & $69.8 \pm 8.8$ \\
\hline 3 & $\begin{array}{l}\text { リノール酸 } \\
\text { パルミチン酸 }\end{array}$ & $\begin{array}{r}5 \\
2.5\end{array}$ & 8 & 4 & $150 \pm 11$ & $226 \pm 33$ & $74.0 \pm 11.5$ & $72.6 \pm 8.2$ \\
\hline 4 & $\begin{array}{l}\text { リノール酸 } \\
\text { パルミチン酸 }\end{array}$ & $\begin{array}{l}5 \\
5\end{array}$ & 8 & 4 & $150 \pm 11$ & $172 \pm 27$ & $74.0 \pm 11.5$ & $129.4 \pm 20.6$ \\
\hline 5 & $\begin{array}{c}\text { 鯨油高度 } \\
\text { 不飽和脂肪酸 } \\
\text { エチルエステル } \\
\end{array}$ & 2.5 & 8 & 4 & $150 \pm 11$ & $179 \pm 12$ & $74.0 \pm 11.5$ & $68.8 \pm 8.2$ \\
\hline 6 & $\begin{array}{c}\text { 觡油高度不飽和 } \\
\text { 脂肪酸エチルエステル } \\
\text { パルミチン酸 } \\
\text { 觔油高度不鴒和 }\end{array}$ & $\begin{array}{c}2.5 \\
1 \\
\end{array}$ & 8 & 4 & $150 \pm 11$ & $210 \pm 21$ & $74.0 \pm 11.5$ & $68.5 \pm 9.7$ \\
\hline 7 & $\begin{array}{c}\text { 鯨油高度不飽和 } \\
\text { 脂肪酸エチルエステル } \\
\text { パルミチン酸 }\end{array}$ & $\begin{array}{l}2.5 \\
2.5 \\
\end{array}$ & 8 & 4 & $150 \pm 11$ & $203 \pm 15$ & $74.0 \pm 11.5$ & $96.8 \pm 5.2$ \\
\hline 8 & $\begin{array}{c}\text { 鯨油高度不飽和 } \\
\text { 脂肪酸エチルエスエル } \\
\text { パルミチン酸 }\end{array}$ & $\begin{array}{c}2.5 \\
5 \\
\end{array}$ & 8 & 4 & $150 \pm 11$ & $187 \pm 35$ & $74.0 \pm 11.5$ & $137.0 \pm 20.1$ \\
\hline 9 & パルミチン酸 & 10 & 8 & 4 & $150 \pm 11$ & $167 \pm 26$ & $74.0 \pm 11.5$ & $220.1 \pm 16.6$ \\
\hline
\end{tabular}


8 群は飼養前の約 $74 \mathrm{mg} \%$ に比べ約 $130 \mathrm{mg} \%, 97 \mathrm{mg} \%$ ， $137 \mathrm{mg} \%$ とそれぞれ増加した。これは表4のコレステロ 一ル低下作用のとさと大体同結果を示した。このように リノール酸と鯨油高度不飽和脂肪酸は共にパルミチン酸

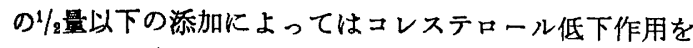
減弱されることはないようである。これについては種々 の飽和脂肪酸, 必須脂肪酸, 不飽和脂肪酸 (オレイン酸) などを用いてさらに検討して行きたいと考えてる。

\section{3. 総括および結語}

1）実験の始めに白ネズミに高コレステロール血を起 こさせる摄取脂質の条件を検討し実際面と合わせ考え， 解子油10\%添加 8 週間以上飼養が適当であることがわか った。

2) そこでこれを用いて高コレステロール血を起こさ せた白ネズミに鯨油高度不飽和脂肪酸（二重結合 4 つ以 上)を投与したところ，3週後にはリノール酸同様血清コ レステロールが低下し，その効力はリノール酸の半量で 有効であった。しかしリノール酸に比べて体重の増加が 少なかった。そこでこの中に $\alpha$ ートコフェロール（抗酸化 用)を加えたところリノール酸同様の体重増加を示した。

3）鯨油高度不飽和脂肪酸のコレステロール低下作用 に及ぼすパルミチン酸の影響はリノール酸と同程度の $1 / 2$ 量以上の添加でその低下作用が減弱された。それは高コ レステロールを起こさせたるのに投与したときおよび最 初より同時添加で長期間飼養したときも同じ結果が得ら れた。

4 ）以上のよ5に鯨油高度不飽和脂肪酸の高コレステ ロール低下作用はリノール酸よりは強いが，飽和脂肪酸 混入による低下作用の減弱度はリノール酸と大体同じよ 5に思われる。

御指導御校閲を睗った原実慶大教授に謹んで感謝の意 を表する。また御協力下さった中野七子，松木光両博士 野々辺皓子栄養士に感謝する。

な婹旨は14, 15回日本栄敾・食糧学会総会で発表し た。
文

献

1) W. Marx, L. Marx and Deuel, H. J. : Am. Heart.J., 42, 124 (1951)

2) J. W. Gofman and F. T. Lindgren et al : Science, 111, 166 (1950)

3) J.W.Gofman and H.B. Jones: Ciruculation, 2, 161 (1950)

4 ) Kinsell, L. W. and Partridge, J. et al: J.Clin. Endocrinol. and Metabolism, 12,909 (1952)

5 ) Kinsell, L. W. and Partridge, J.et al : J.Clin. Nutrition, I, 224 (1953)

6 ) Ahrens, E. H. Jr., Blankenhorn, D. H.and T.T. Tsaltas: Proc. Soc. Exptl. Biol. Med., 86,872 (1954)

7 ) Beveridge, J. M. R., Connell, W.F. et al :J. Nutrition., 56, 311 (1955)

8 ) Bronte-Stewart, B., Keys, A. et al : Lancet, II, 1103 (1955)

9) Malmros, H. and Wigand, G. : Minn.Med., 38, In Symposium on Arteriosclerosis. University of Minnesota (1955)

10) Ahrens, F. H., Peterson, M. L. et al : Lancet, I, 943 (1957)

11) Kinsell, L. W., Michaels, G. D. et al : Circulation, 14, 484 (1956)

12) Friskey, R. W. , Michaels, G. D. and Kinsell, L. W. :Circulation, 12, 492 (1955)

13) Bronte-Stewart, B. and Antonis, A. : Lancet, I, 521 (1956)

14) Ahrens, E.H.Jr.: Proc.Soc. Exp. Biol. Med., 86, 872(1954)

15) Ahrens, E.H.Jr.et al : J.Clin. Invest., 34,918 (1955)

16) Kinsell, L. W., Michaels, G.D.et al: $A m . J$. Clin. Nutrition, 3, 247 (1955)

17) Keys, A., Antonis, A. et al: Lancet, I, 66 (1957)

18) Malmros, H., Wigard, G.et al : Lancet, II, 1 (1957)

19) Eggstein, M.et al : Cited in "Essential Fatty Acids"ed.by H. M. Sinclair, (Butterworth Publ. London) p. 111 (1958)

20) Worne, H. E. et al : Am.J.Med. Soc, 333, 718 (1959)

21) Kingsbury, K. J.et al: Lancet, I, 739 (1961)

22) Walker, G.et al: Lancet, I, 286 (1959)

23) Schönheimer, R. and Sperry, W. M. : J.Biol. Chem., 106, 745(1934)

24) Zak, B.et al: Am.J.Clin. Path., 24, 1307 (1954)

25) Wissler, R.W.et al : Federation Proc., 12, 407 (1953)

26) Boyd: J.Biol.Chem., 143, 131 (1942)

27) Hillyard et al : I. Biol. Chem, 214,79 (1955)

28) Kohn: Amer.J.Physiol., 163, 410 (1950)

29) 馬嶋安正, 栗原文男, 14回日本栄盖- 食糧学会総会 (1960)

30) Hegsted, D. M. et al: J. Nutrition., 63, 377(1957)

31) Hegsted et al:J. Nutrition, 70,119 (1960)

32) Keys, A.et al : Lancet, I, 787 (1957) 